
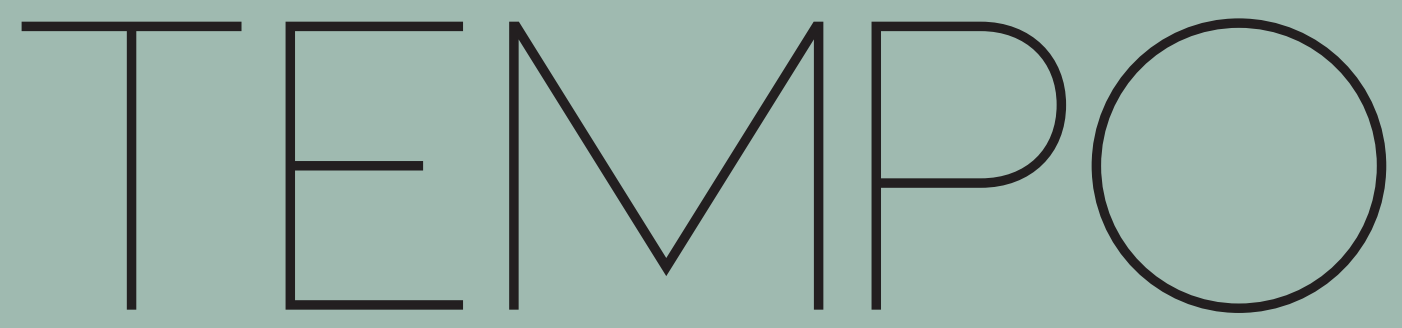

A QUARTERLY REVIEW OF NEW MUSIC

EDITORIAL: TOO MUCH NOISE?

'SUBTLE SHIFTS': HOWARD SKEMPTON'S TWENTY-FIRSTCENTURY MODERNISM

ARNOLD WHITTALL

'THE BRIGHT PLACES OF LIFE AS CLEARLY AS THE DARK':

THE MUSIC OF LINDA BUCKLEY

CHRISTOPHER FOX

REFRAMING THE LISTENING EXPERIENCE THROUGH

THE PROJECTED SCORE

DAVID KIM-BOYLE

NEW HORIZONS IN BRAZILIAN CONTEMPORARY

MUSIC: GRUPO NOVO HORIZONTE DE SÃO

PAULO, 1988-99

\title{
CHRISTOPHER DROMEY
}

SEVENTIETH BIRTHDAY PIECES FOR HOWARD SKEMPTON BY LAURENCE CRANE, MICHAEL FINNISSY,

CLAUDIA MOLITOR, GENEVIEVE MURPHY,

LINDA C. SMITH, JAMES WEEKS

REVIEWS: FIRST PERFORMANCES, CDS, AND BOOKS

PROFILE: JOBINA TINNEMANS

ARTWORK: GENEVIEVE MURPHY 


\section{TEMPO}

EDITOR Christopher Fox

tempoeditor@cambridge.org

REVIEWS EDITOR Heather Roche

temporeviewseditor@gmail.com

ADVERTISING

Email (UK and rest of the world)

ad_sales@cambridge.org

Email(US) USAdsales@cambridge.org

SUBSCRIPTION ENQUIRIES

Tel: 01223326070

Email: journals@cambridge.org

\section{ADVISORY BOARD}

Amy C. Beal

University of California, Santa Cruz, USA

Davinia Caddy

University of Auckland, New Zealand

Jonathan Cross

University of Oxford, UK

Mark Delaere

KU Leuven, Belgium

Kyle Gann

Bard College, USA

James Gardner

Auckland, New Zealand

Gisela Gronemeyer

Cologne, Germany

Anna Höstman

Toronto, Canada

Peter Hill

University of Sheffield, UK

Nicholas Jones

Cardiff University, UK

Gerard McBurney

London, UK

François-Bernard Mâche

Paris, France

Olivia Mattis

Huntingdon, New York, USA

David Metzer

University of British Columbia, Canada

Tim Rutherford-Johnson

London, UK

Howard Skempton

Leamington Spa, UK

\section{Mission Statement}

As a 'Quarterly Review of New Music', TEMPO exists to document the international new music scene while contributing to, and stimulating, current debates therein. Its emphasis is on musical developments in our own century, as well as on music that came to prominence in the later twentieth century that has not yet received the attention it deserves.

\section{Subscriptions}

TEMPO (ISSN 0040-2982) is published four times a year in January, April, July and October. Four parts form a volume. The subscription price for volume 72 (Nos. 283-286), which includes delivery by air where appropriate (but excluding VAT) is $£ 154$ (US \$257 in USA, Canada and Mexico) for institutions (print and electronic); $£ 125$ (US \$212) for institutions (electronic only); £31 (US \$52) for individuals ordering direct from the publishers and certifying that the journal is for their personal use (print only). EU subscribers (outside the UK) who are not registered for VAT should add VAT at their country's rate. VAT registered members should provide their VAT registration number. Japanese prices for institutions (including ASP delivery) are available from Kinokuniya Company Ltd, P.O. Box 55, Chitose, Tokyo 156, Japan.

Orders, which must be accompanied by payment, may be sent to a bookseller, subscription agent or direct to the publisher: Cambridge University Press, Journals Fulfilment Department, UPH, Shaftesbury Road, Cambridge CB2 8BS; or in the USA, Canada and Mexico: Cambridge University Press, Journals Fulfillment Department, One Liberty Plaza, New York, NY 10006, USA. Periodicals postage paid at New York, NY and at additional mailing offices.

\section{Copying}

This journal is registered with the Copyright Clearance Center, 222 Rosewood Drive, Danvers, MA 01923, USA. Organizations in the USA who are also registered with the C.C.C. may therefore copy material (beyond the limits permitted by sections 107 and 108 of U.S. Copyright law) subject to payment to the C.C.C of the per copy fee of $\$ 12$. This consent does not extend to multiple copying for promotional or commercial purposes. Code 0040-2982/2018 \$12. ISI Tear Sheet Service, 3501 Market Street, Philadelphia, PA 19104, USA, is authorized to supply single copies of separate articles for private use only. Organizations authorized by the Copyright Licensing Agency may also copy, material subject to the usual conditions. For all other use, permission should be sought from Cambridge or from the American Branch of Cambridge University Press.

This journal is included in the Cambridge Journals Online service which can be found at journals.cambridge.org.

This journal issue has been printed on FSC-certified paper and cover board. FSC is an independent, non-governmental, not-for-profit organization established to promote the responsible management of the world's forests. Please see www.fsc.org for information.

Printed in the UK by Bell \& Bain.

cover design: Studio Isabelle Vigier

(C) Cambridge University Press 2018 


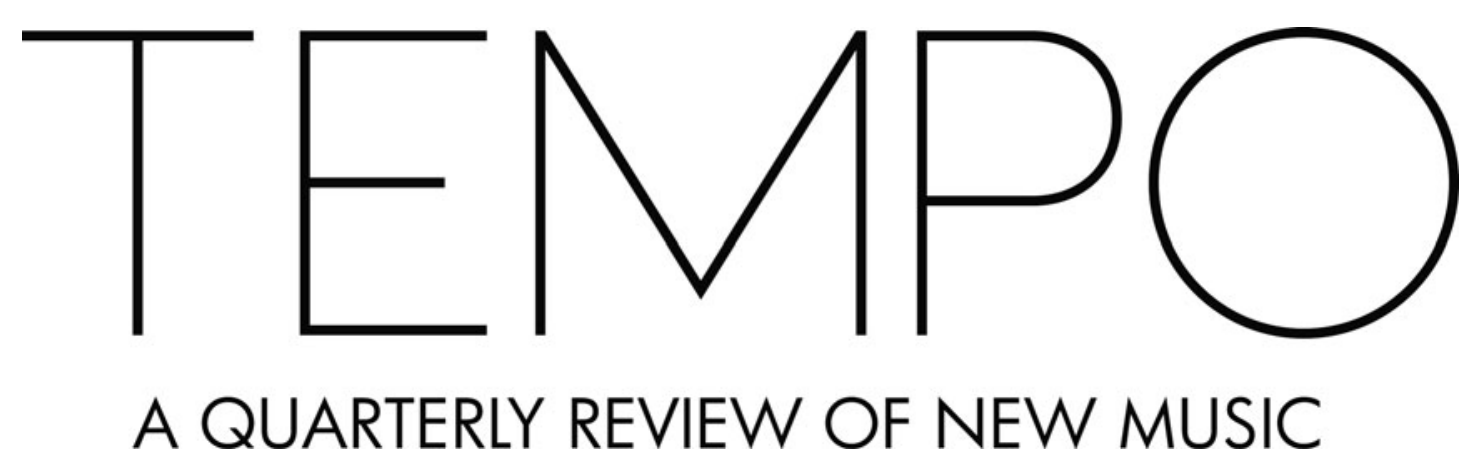

EDITOR Christopher Fox / REVIEWS EDITOR Heather Roche

VOLUME 72 NO. 284 APRIL 2018

3 EDITORIAL: TOO MUCH NOISE?

Christopher Fox

6 BIRTHDAY PIECE FOR HOWARD SKEMPTON: HE RODE THE THERMALS

Laurence Crane

7 'SUBTLE SHIFTS': HOWARD SKEMPTON'S TWENTYFIRST-CENTURY MODERNISM

Arnold Whittall

20 BIRTHDAY PIECE FOR HOWARD SKEMPTON: UNBROKEN Linda C. Smith

22 'THE BRIGHT PLACES OF LIFE AS Clearly as THE DARK': THE MUSIC OF LINDA BUCKLEY

Christopher Fox

36 BIRTHDAY PIECE FOR HOWARD SKEMPTON: DURHAM James Weeks

37 REFRAMING THE LISTENING EXPERIENCE THROUGH THE PROJECTED SCORE

David Kim-Boyle

51 BIRTHDAY PIECE FOR HOWARD SKEMPTON: PREPARE \& PLAY

Claudia Molitor

52 NEW HORIZONS IN BRAZILIAN CONTEMPORARY MUSIC:

GRUPO NOVO HORIZONTE DE SÃO PAULO, I988-99

Christopher Dromey

68 ARTWORK: GENEVIEVE MURPHY

69 BIRTHDAY PIECE FOR HOWARD SKEMPTON: WERE WE BORN YESTERDAY?

Michael Finnissy 
FIRST PERFORMANCES

70 DONAUESCHINGEN 2017 Max Erwin

74 GAIDA FESTIVAL 2017 Claire McGinn

76 HCMF 2017 Stephen Chase

80 ICEBREAKER: TINNEMANS, MEREDITH, KELLY, ANDREWS, BUCKLEY, MOORE Natalie Raybould

81 RAINY DAYS $20 I 7$ Athena Corcoran-Tadd

CDs AND DVDs

84 REMIX ENSEMBLE, ANAMORPHOSES: JOHANNES

SCHÖLLHORN Aaron Holloway-Nahum

85 THREE ANOTHER TIMBRE RELEASES: JENNINGS, CAGE, FREY Ben Harper

87 ENSEMBLE ADAPTER, CHAMBER WORKS: FRANCO DONATONI Christian Carey

88 LONGLEASH, PASSAGE: TRAPANI, IANNOTTA, WATANABE, FILLIDEI Paul Steenhuisen

89 DUO IMAGINAIRE, JAPANESE ECHOES: MIYAKI, MINAMI, YAMAGUCHI, FUSI, OMURA, RAI, DEBUSSY Lauri Supponen

BOOKS

91 CAMPBELL: LOU HARRISON: AMERICAN MUSICAL MAVERICK, BY BILL ALVES AND BRETT CAMPBELL Tim Rutherford-Johnson

93 COMPOSER GENEALOGIES, BY SCOTT PFITZINGER MaX Erwin

95 CONVERGENCES, DIVERGENCES AND AFFINITIES, BY TREVOR BARRE Richard Barrett

98 BIRTHDAY PIECE FOR HOWARD SKEMPTON: DRIP (FOR ACCORDION AND VIOLA) Genevieve Murphy

100 PROFILE: JOBINA TINNEMANS

104 CONTRIBUTORS 